\title{
Political and Social Status of Women in Pre and Post Independent India
}

\section{OPEN ACCESS}

Manuscript ID:

ASH-2020-08023289

Volume: 8

Issue: 2

Month: October

Year: 2020

P-ISSN: 2321-788X

E-ISSN: 2582-0397

Received: 23.07.2020

Accepted: 29.08.2020

Published: 01.10.2020

Citation:

Sudalai Moni, T. "Political and Social Status of Women in Pre and Post Independent India." Shanlax International Journal of Arts, Science and Humanities, vol. 8, no. 2, 2020, pp. 77-82.

DOI:

https://doi.org/10.34293/ sijash.v8i2.3289

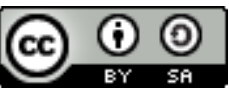

This work is licensed under a Creative Commons Attribution-ShareAlike 4.0 International License

\section{T. Sudalai Moni}

Research Scholar in History, Madurai Kamaraj University, Madurai, Tamil Nadu, India

(D) https://orcid.org/0000-0002-7242-5425

\begin{abstract}
Women's involvement in socio-political life is a desideratum for the progress of not only the women folk but also the development of the nation as a whole. During ancient and medieval times, women from orthodox families actively participated in social activities, but their overall position and status gradually deteriorated. The Modern era meant for women ushered in during the dawn of the 19th century when social reformers paid special attention to enhance the social status of women. For instance, the promulgation of the Widow Remarriage Act, implementation of the Civil Marriage Act 1872 mentions a few of them. Ever since the formation of the Indian National Congress, several remarkable changes took place in the socio-political status.

Moreover, women franchise induced their effective participation in the Freedom Movement of India. They were accorded equal political status on par with men only after independence, which has been enshrined and enumerated in the provisions of fundamental rights of the Indian constitution. In the new millennium, there has been constant demand to accord 33 percentages of reservations to enhance the status of women in the political arena as well as to increase their social statues. This paper attempts to indicate the socio-political status of women over the period in the Indian context during the Pre and Post Independent India.
\end{abstract}

Keywords: Empowerment, Freedom, Franchise, Independent, Social Status and Movement

\section{Introduction}

This paper attempts to delineate the socio-political status of women during the Pre and Post Independent India as historical events stand to indicate that obviously, their socio - political status in medieval times were severely jeopardized due to several obnoxious social evils such as Child Marriage, Purdha System, Sati, and Polygamy. Despite these severe shortcomings, however, the 18th and 19th centuries witnessed and heralded a tremendous transformation in the socio-political status of women, which era has been appropriately rechristened as the modern epoch for Indian women folk.

Paradoxically, the social reformer's special attention and the consistent efforts of the Indian National congress catapulted the transformation of the social status of women in India. Inspired by the revivalist consciousness of women, the formation of the Women's Association, such as Sarda Sadan and Seva Sadan, strived to achieve their long-pending demands. The sanction of Women Franchise is yet another mile stone which encouraged them to compete to score and secure equal status on par with men. The participation of women in the freedom movement and their subsequent involvement in the Post Independent politics and the political process are highlighted in this paper. Efforts made to implement the $33 \%$ quota of reservation for women in the Upper and Lower houses of the Indian Parliament are also discussed in this paper.

\section{Medieval Times}

Medieval Indian history spread over almost five hundred years (A.D. 1200 to A.D. 1700). It is predominantly the history of Muslim rulers. Also, a new 
Sikhism two emerged in India as a religion during this period, and the Bhakti movement became very popular during then. The medieval times witnessed the position and status of woman got deteriorated. They were considered weak, and it was the responsibility of men to protect them. As they were sensitive in temperament, they should be treated with love and care; and were considered dependent on men throughout their lives. ${ }^{1}$ Due to the spread of Islam, during this period in India, women were permitted equal instructions with men in the early days of this period. Due to obnoxious social restriction and rigidity of norms towards women, several evil practices such as Infant Marriages, the Purdha System, Sati, Polygamy, Dowry System, and Female Infanticide sprang up which eroded the Indian social fabric. Muslim women, although suffered during this period, those who belong to the royal families took an active part in the social \& political life. However, strict seclusion. ${ }^{2}$ It may be surmised that the entire stretch of medieval times was thus characterized by social seclusion and negation of decent treatment of women. Neither in domestic life nor public sphere of activities had they ever been accorded a decent status.

\section{Women during $18^{\text {th }}$ and $19^{\text {th }}$ Centuries}

The participation of Indian women in politics in the modern era started in the late 18th and early 19th centuries. British imperialism in India had profoundly influenced the political engagement of both elite and non-elite women folk during this period. In general, women also participated and fought against the British colonialists in the late 18th \& 19th centuries and other such revolts in the nineteenth century. ${ }^{3}$

The political status of women during this time depended on the situation and the then existing political system in the country. Since the political system in Ancient and Medieval India was based on monarchy, there were no legislatures, political parties, diplomatic relations, and International

1 Rani, Kala. Role Conflict in Working Women, Chetana Publications, 1976.

2 Jharta, Bhawana. Women and Politics in India: Impact of Family and Education on Women Political Activists, Deep \& Deep Publications, 1996.

3 Roy, Kalpana. Women and their Environment, Rajat Publications, 1999.
Conferences. In such situations, giving voting rights or freedom for contesting elections and holding political posts to common women did not arise. During Modern times, the early social reformers focused their special attention on the social status of women. For instance, Raja Ram Mohan forcibly attacked the inhuman practice imposed upon women in the shape of Sati and the unhappy treatment meted out to widows. Resultantly that Lord William Bentinck passed the "Regulation No XVII" on 4th December 1829, which declared Sati as illegal and a punishable offense by criminal courts. ${ }^{4}$

Ishwar Chandra Vidyasagar took a leading part in promulgating the Widow Remarriage Act of 1856 to make the widow marriage legal and provide and protect a status to the Hindu, Widow in Society. The efforts of Keshab Chandra Sen against early marriage, facilitated the enactment of the Native Marriage Act, known as the Civil Marriage Act of 1872. Since then, for the awakening among woman, the services rendered by Rama Krishna Mission, Theosophical Society, and the Arya Samajare exemplary. ${ }^{5}$ The other notable social reformers include were RavinderNath Tagore, Swami Dayanand Saraswati, Swami Vivekanand, Gopal KrishanGokhale and Annie Besant, E.V.Ramasamy, Narayana Guru, to mention only a few of them. ${ }^{6}$ During the late nineteenth century, various social organizations emerged focusing towards reforms of women. The Indian National Congress (INC) also attempted to focus on bringing favorable changes in the socioeconomic and political status of women since its formation in 1885. The Indian National Congress (INC), the first National Party, organized in 1885, has taken steps to uplift women's status in India. The leaders of INChad profound respect for women and encouraged them to play a leading role in freedom movements, such as Civil Disobedience and Satyagrahas. $^{7}$

4 Pandey, Sumana. Women in Politics, Rawat Publications, 1990.

5 Majumdar, Ramesh Chandra. The History and Culture of the Indian People: The Age of Imperial Unity, Bharatiya Vidya Bhavan, 1951.

6 Sachidananda, Ramesh Sinha. Women's Rights: Myth and Reality, Printwell Publishers, 1984.

7 Mehta, G.S. Participation of Women in Panchayati Raj System, Kanishka Publishers, 2002. 


\section{Revivalist Consciousness}

Due to the growing influence of the revivalist consciousness of many women organizations, societies, Samiti came into existence, which created an awakening among the women and gradually came forward to claim their democratic rights. For instance, The Ladies Association (1886), SardaSadan (1892), Gujrati Hindu Stree Mandal (1908), SevaSadan (1909). ${ }^{8}$ Due to the efforts of the All India Women's Conference (AIWC 1927), equal right to Indian women were granted by the British. ${ }^{9}$ Subsequently, the issue of women's franchise began to receive increasing attention and attraction during this period. ${ }^{10}$

\section{Towards Women Franchise}

In 1921 women got the right to vote in the election of Madras Legislative Council. Gradually, Indian Legislature one after another started enfranchising women of their respective provinces on the same term as men. ${ }^{11}$ In 1926; Mrs. Kamla Devi Chattopadhyay and Mrs. Hannath were the first women to contest the election to Legislature Assembly. ${ }^{12}$ However, amongst the Indian States, Travancore was the first to give representation to Women. Smt. Madhani Ammal was nominated to Cochin Legislative Council. In Madras, Mrs. Muthulakshmi Reddy was nominated to the Legislature Council. The All India Women's conference was held in 1926 for the upliftment of women. However, at the end of thirties, it found itself inextricably involved in the independence movement of India. ${ }^{13}$

\section{Women and Freedom Movement}

The Participation of women in the freedom

8 Asthana, Pratima. Women's Movement in India, Vikas Publishing House, 1974.

9 Roy, Kalpana. Women and their Environment, Rajat Publications, 1999.

10 D'Lima, Hazel. Women in Local Government: A Study of Maharashtra, Concept Publishing Company, 1983..

11 Asthana, Pratima. Women's Movement in India, Vikas Publishing House, 1974.

12 Thomas, Paul. Indian Women Through the Ages, Asia Publishing House, 1964.

13 Vats, Poonam. Political Participation and Attitudinal Transformation of Rural Women, Abhijeet Publications, 2004. movement was unprecedented. In September 1931, representatives of various women's organizations in India met in Mumbai with Mrs. Sarojini Naidu as their President. They drafted a memorandum demanding "the immediate acceptance of adult franchise without any sex discrimination". ${ }^{14}$ The British Government turned it down. However, in 1931 Karachi Session of Indian National Congress took the historic decision of committing itself to political equality of women, regardless of their status and qualification. As President of the Indian National Congress, Jawaharlal Nehru accepted equal political rights and legal rights of women and introduced the concept of equal obligations and equal rights in the fundamental rights resolution passed by Congress that year in March 1931.

The Government of India Act, 1935, increased the number of enfranchised Indians (approximately 30 million Indians, some women gained voting rights - around $14 \%$ of the population). This act made provisions for proportional suffrage rights of women and revised some of the previous qualifications. All women over 21 years of age could vote, provided they fulfilled the conditions of property and education. This act included reserved seats for women and several women prepared for political office. After the 1935 Act, the first elections to Provincial Legislatures were held in 1937, in which female electorates were greatly expanded so that approximately nine percent of the adult females were enfranchised. It was the first time in Indian history fifty-six women entered the Legislatures.

There were forty-one seats reserved for women in Provincial Legislative assemblies, ten women won unreserved seats, and five were nominated to provisional Legislative Councils. In 1939 A.D., the tide of political, educational, and social honor for women has risen so high that India had more than 80 women members in its Legislatures of Provinces and States. (in 11 provinces). During the 1942 'Quit India Movement,' when all the top leaders were arrested, and the movement became practically leaderless, women joined hands with the male folk. They carried it on by taking out processions, holding meetings, demonstrations, and organizing strikes. Women did

14 Thomas, Paul. Indian Women Through the Ages, Asia Publishing House, 1964. 
not only actively participate in the Independence of India, but they also played a significant role in drafting the Indian Constitution. The Constituent Assembly, constituted in October 1946 (a body elected by the existing Legislatures), had among its members Sarojini Naidu, Durgabai, Renuka Ray, and Hansa Mehta. ${ }^{15}$ Out of 299 members, there were 15 women representatives. The Constitution of India came into effect on 26 January 1950. The total membership of the constituent assembly was 389 , in which there were 15 female members who contributed their might to this. ${ }^{16}$

\section{Women Participation in Politics after Independence}

After Independence, provision was made in the Indian constitution to provide equal rights and opportunities for social, economic, and political development and betterment of living for women. With the advent of Independence, Indian women were guaranteed political equality with men. The Fundamental Rights enshrined in Article 14, 15, and 16 guarantees the principle of equality before the law, equality of sexes, and equal opportunities to all citizens of India in all lifestyles. Article 325 makes no special electoral rolls on the grounds of religion, race, caste, or sex. Article 326 emphasizes that election to the legislative assemblies of the state were to be held based on adult franchise. In addition to this, various initiatives have been undertaken to bring improvements in the socio-economic status and empowerment of women. Article 39 (a) states, the state shall direct its policy towards securing that the citizens, men and women, equally have the right to an adequate means of livelihood and article 39 (d)equal pay for equal work for both men and women. Article 42provides for securing just and humane conditions of work and maternity relief, and Article 51 A (e) provides that it shall be a fundamental duty to every

15 Thomas, Paul. Indian Women Through the Ages, Asia Publishing House, 1964.

16 Those 15 female members were: Ammu Swaminathan (Kerala), Dakshayanivelayudham (Cochin), Begum Aizaz Rasul (UP), Durgabhai Deshmukh (AP), Hansa Jivraj Mehta (Baroda), Kamala Chaudhary (Lucknow), Leela Roy Malathy chaudhary (East Bengal), Purnima banerjee(UP), RajkumariAmrit Kaur (UP), Renuka Roy (West Bengal), Sarojini Naidu, Sucheta Kriplani (Harayana), Vijalakshmi Pandit (Allahabad) and Annie Mascarene (Kerala). citizen of India to renounce practices derogatory to the dignity of women. These provisions and Fundamental Rights envision a new socio-political order on equality and equity of women in India.

\section{Women in the Political Process - Post Independent Scenario}

After independence, Indian women slowly began to realize that the actualization of promises of equality is not a smooth process. As the euphoria over newly won freedom subsided, the complicated and intricate pattern of politics became clear with its variations of castes, languages, religions, and divisions of family structures and cultural traditions. Indian women thus realized the barriers of caste, class, language, religion, and region and the consequent complexity of these issues and difficulties encountered in handling them. Participation in the freedom struggle had not generated any controversy on gender roles. The assimilation of women in the struggle to free the nation had given them confidence and access to the positions of power and responsibility. Still, the positions of power were not within easy reach. ${ }^{17}$

\section{Women Representation: Indian Political Scene}

The Empowerment of women in the economic, social, and political arena has become one of the most important concerns of the 21 st century. It is central to the issue of equality, justice, and liberation in the country. Women constitute almost half of the world's population. However, they are the most deprived and unproductive members of the economy of many world nations. Promoting various incomegenerating activities, especially among rural women, is perceived as one of the most powerful mediums to resolve several socio-economic and even political problems. Empowerment is a process of awareness and capacity building, leading to greater participation and greater decision-making power. The process of empowerment strengthens one's innate abilities through acquiring knowledge, power, and experience. ${ }^{18}$

17 Desai, Neera, and Usha Thakkar. Women and Political Participation in India, 2000.

18 Murugan, K.R., and B. Dharmalingam. "Self Help Groups- New Women's Movement in Tamil Nadu." Social Welfare, 2000, pp. 9-12. 


\section{Women Empowerment}

Women empowerment in general and poor women in particular is the thrust area of development initiatives in India today. Empowerment of women is a process whereby women can organize themselves in Community based participatory groups to increase their self-confidence, self-reliance, assert their independent rights. Further to counter and challenge the disparities and barriers against them, make prudent choices and control resources, which will assist in challenging and eliminating their subordination thereby, bringing a beneficial social- economic and political change. ${ }^{19}$ For Several Centuries, during medieval times and during the time of British imperialism, the freedom, rights, and privileges of women were curtailed. ${ }^{20}$ It was only in the twentieth century Mahatma Gandhi prophetically said, "as long as the women of India do not take part in public life, there can be no salvation for the country.

It is worth mentioning that way back in 1920, Smt. Sarojini Naidu and Ms. Margaret Cousins led a group of women to demand equal rights of representation for the fair sex in the Indian Provincial Legislatures. Lokmanya Bal GangadharTilak believed that political action on the part of women could be independent of their social status and that political action was possibly more important than social 1 reform in empowering women. In independent India, women have held important political and administrative positions. Political representation was initially based on the premise that it deals primarily with individuals. It was believed that though very few women were joining politics at a given time, the overall improvement in terms of education and employment opportunities would necessarily percolate into the political sphere too and their representation would commensurately increase.

To conclude, the study reveals the fact that most parts of India are even today patriarchal; in the

19 Khan, Mohd Asif, and K.M.Nisha. "Kudumbashree as a Catalyst for Economic Empowerment of Rural Women through Self Help Groups in Kerala." IOSR Journal of Business and Management (IOSR-JBM), vol. 16, no. 9, 2014, pp. 33-41.

20 Barki, Sreedhar. "Issues of Women Representation and Women in Indian Parliament." International Global Research Analysis, vol. 12, no. 10, 2013, pp. 101-102. sense that women are being denied the privilege to participate in public life. Not only that, all-important issues associated with local politics are an exclusive domain of men. It must be recalled that the status of women in the Pre- independent times was so much deplorable and despicable. This sordid state of affairs was attributed to the prevalence of male dominance.

Though women constitute, as of now, around $48.46 \%$ of India's total population, the constitutional provisions have not been adequate to accommodate and enhance their socio-political status. For instance, Article-14 stresses equal rights and opportunities to both men and women in all matters concerning political, economic, and social spheres. But, in reality, it remains a mirage so far as women are concerned. Indian women were/are generally engaged in domestic chorus, especially in the rural areas. In most households, either the husband or the father alone is the decision making authority in all the matters relating to the family. Thus, the structure of the family is so fabricated that men excise absolute control over the household, due to which the massive majority of women are in subordination.

Despite the Indian government's initiative to address and resolve women's issues, largely their expectations laid to rest. Of late, there has been a tremendous change in the women's literacy ratio, which has increased multifold compared to men, but still, women are kept in the backyard. Modern India witnesses active political participation of women in the various affairs through the Panchayat raj system. Undeniably their lifestyle also has changed, which enhanced their social status. The Women's Reservation Bill was passed by the Rajya Sabha in 2008, granting them 33 percent reservation of seats, both in the Lok Sabha and State Legislative Assemblies across India. But, most unfortunately, this most anticipated and awaited Bill is still kept pending in the Lok Sabha, though the Rajya Sabha passed the Bill on 9 March 2010.

It is desirable to note that the Women Reservation Bill or any other crucial and sensitive issues related to women's political participation should not be a subject matter to curry the favor of electorates at the time of elections. But it should be accorded due priority. It is insisted that it must be a continuous and consistent process of consideration in granting 
Equal Rights and Equal Status to Indian Women Folk. Most specifically, certain concerns such as the sense of insecurity, caste barriers, financial constraints, and social negation and such other serious issues involving women should be addressed forthwith without any procrastination if these issues are resolved, which would encourage them for more meaningful and proactive participation in every aspect of socio, economic and political arena.

Desirably, a grass root level approach may be initiated, which would enable them to overwhelming their entry-level hesitations and barriers. Not only that, all political parties should consider and come forward to nominate more women representatives, not only in their internal working committees besides fielding them in large numbers to contest in the Elections. Though women constitute about fifty percent of the Indian population, a reservation of a mere 33\% for women is still under representation in legislatures. Honest and sincere efforts are required from both the Central and State Governments to push towards a promising percentage that would adequately represent the dreams and aspirations of women folk across India.

\section{Author Details}

T. Sudalai Moni, Research Scholar in History, Madurai Kamaraj University, Madurai, Tamil Nadu, India,

Email:tsmoni01@yahoo.com. 